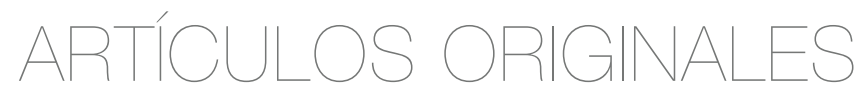

\title{
Perceived Internal Employability as a Strategy to Reduce Employee Intention to Quit
}

\author{
ÁNGELA MARÍA SÁNCHEZ SÁNCHEZ-MANJAVACAS* \\ LORENZO REVUELTO TABOADA** \\ MARÍA DEL CARMEN SAORÍN IBORRA***
}

* PhD in Economic and Business Sciences. Instituto Superior de Estudios Profesionales, Universidad CEU Cardenal Herrera, Valencia, España. E-mail: fol.eie.ciclos@gmail.com. ORCID: 0000-0002-1248-5063. Google Scholar: https://scholar.google. es/citations?user=x82ByGMAAAAJ\&hl=es\&oi=sra.

** PhD in Economic and Business Sciences. Universitat de València, Valencia, España. E-mail: lorenzo.revuelto@uv.es. ORCID: 0000-0002-4957-8626. Google Scholar: https://scholar.google.es/citations?user=sKmwC9EAAAAJ\&hl=es\&oi=ao.

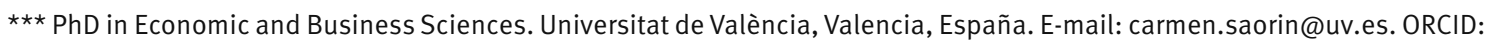
0000-0001-8765-9948. Google Scholar: https://scholar.google.es/citations?user=40B-TJcAAAA\&hl=es\&oi=ao. 


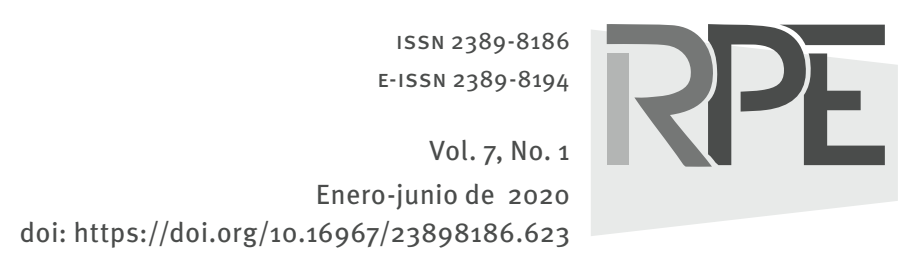

COMO CITAR ESTE ARTÍCULO

How to cite this article:

Sánchez, Á.M., Revuelto, L. and Saorín, M.C. (2020). Perceived Internal Employability as a Strategy to Reduce Employee Intention to Quit. Revista Perspectiva Empresarial, 7(1), 7-23.

Recibido: 06 de noviembre de 2019

Aprobado: 22 de enero de 2020
ABSTRACT This study analyzes the impact of perceived internal employability as a means to retain employees who possess human capital valuable for the company. Employees' perceptions are used since these are the ones which determine attitudes and, therefore, predispositions to act, as well as adopted individual behaviors. Job satisfaction and organizational commitment are proposed as mediating variables in such relationship, since they have been mentioned in the literature as determinants when explaining employee behavior. Intention to quit job is used as dependent variable insofar as it is very complex to analyze effective employee turnover, which depends to a great extent on the opportunities offered by the labor market. The analysis is carried out through structural equations in a sample of 218 employees. The results show that internal employability does have a positive effect in a combined affective dimension of the job, and that this dimension has a negative impact on employees' intention to quit their jobs.

KEY WORDS internal employability, intention to resign from work, job satisfaction, organizational commitment.

\section{La empleabilidad interna percibida como estrategia para reducir la predisposición a renunciar de los empleados}

RESUMEN Este estudio analiza el impacto de la empleabilidad interna percibida como un medio para retener empleados poseedores de capital humano valioso para la empresa. Se utilizan las percepciones de los empleados puesto que son estas las que determinan las actitudes y por lo tanto las predisposiciones para actuar, así como los comportamientos individuales adoptados. La satisfacción laboral y el compromiso organizativo se proponen como variables mediadoras de dicha relación, pues se han manifestado como determinantes en la literatura a la hora de explicar el comportamiento de los empleados. Como variable dependiente se utiliza la intención de renunciar al trabajo dado que es muy complejo analizar la rotación efectiva de los empleados, la cual depende en gran medida de las oportunidades que ofrece el mercado laboral. El análisis se lleva a cabo a través de ecuaciones estructurales en una muestra de 218 empleados. Los resultados muestran que la empleabilidad interna sí tiene un efecto positivo en una dimensión afectiva combinada del trabajo, así como esta última dimensión impacta negativamente en la intención de los empleados de renunciar a su trabajo.

PALABRAS CLAVE empleabilidad interna, intención de renunciar al trabajo, satisfacción laboral, compromiso organizativo. 


\section{Empregabilidade interna percebida como estratégia para reduzir a disposição a renunciar dos funcionários}

RESUMO Este estudo analisa o impacto da empregabilidade interna percebida como um meio de reter os funcionários com valioso capital humano para a empresa. As percepções dos funcionários são utilizadas, pois são elas que determinam atitudes e, portanto, predisposições para agir, bem como os comportamentos individuais adotados. A satisfação no trabalho e o comprometimento organizacional são propostos como variáveis mediadoras dessa relação, uma vez que foram mostrados como determinantes na literatura quando se trata de explicar o comportamento dos funcionários. A intenção de deixar o trabalho é usada como variável dependente, pois é muito complexa analisar a rotatividade efetiva dos funcionários, que depende em grande parte das oportunidades oferecidas pelo mercado de trabalho. A análise é realizada por equações estruturais em uma amostra de 218 funcionários. Os resultados mostram que a empregabilidade interna tem um efeito positivo em uma dimensão afetiva combinada do trabalho, assim como essa última dimensão afeta negativamente a intenção dos funcionários de deixar o emprego.

PALAVRAS-CHAVE empregabilidade interna, predisposição para deixar o trabalho, satisfação no trabalho, comprometimento organizacional. 


\section{Introduction}

In today's working environment, being employable is almost as crucial as having a stable job. Indeed, from a long-term standpoint it is even more so, because in most cases a job is only stable until it is not. Employability determines a worker's options for finding employment with relative ease together with their ability to meet the requirements of a constantly changing labor market. This can only be achieved and maintained through having and continuously updating a blend of skills, knowledge, experience, aptitudes and attitudes. Hence, becoming flexible and having the ability to adapt and learn new technologies and working procedures are key long-term skills. As a result, employability is a talent that should be cultivated not only by job seekers but also by people who are already employed. It is additionally an opportunity for companies to reverse, at least in part, the growing trend towards the development of increasingly negative attitudes towards work and the company (low and declining satisfaction and commitment levels, in addition to an increasing inclination to quit among key employees) (Pfeffer, 2007).

As it is well known, the Spanish labor market has changed considerably in a short period of time due, among other things, to a dominant duality in labor relations, namely a divide between precarious jobs and contracts with greater stability. This complexity means that thought needs to be given to the relevance of lifelong learning as a way of updating personal skills and developing our abilities throughout our working lives, promoting mechanisms that help stimulate changes in employees which also engender a greater intention to stay in a company. From an organizational standpoint, it is important to try to reverse, or at least mitigate, the perception of many employees that the psychological contract has been breached when they see how the companies they work for, or are considering working for, neither want nor in many cases are able to ensure long-term employment in exchange for loyalty, commitment and productivity.

It is true that the circumstances of prolonged economicrecession that led to high unemployment, reduces employees' expectations and increases their "obligatory tolerance" for precarious employment relationships and low investment in training. However, from a long-term perspective, companies should consider providing reasonable rewards in return for what they require from their employees, such as guaranteeing if not their jobs, then at least that these employees will maintain their employability intact or even increase it. In other words, the implicit promise that if an employee loses their job at the company, the training, skills and knowledge they have acquired there will be useful when they need to find a new one as their employability has been maintained (Fernández-Mateo, 2002).

The intention would be to build genuine engagement between organization and employee with real options for progress for both sides, not to mention the relevance from the perspective of internal corporate responsibility. The foregoing also means that thought needs to be given to the relevance of lifelong learning as a way of updating personal skills and developing our abilities throughout our working lives. Education and training are consequently essential mechanisms for promoting employability and thus adequately coping with a society marked by the constant evolution of science and technology (Fallows and Steven, 2000; Nilsson and Ekberg, 2013).

As noted above, the high degree of uncertainty of contemporary working life means that employees need to fight to generate new challenges in managing their careers and thus add to their professional talent (Nilsson and Ellström, 2012) through effective changes in the contents of their work as well as updating their skills and/ or rotation in various training programs (Riddell and Sweetman, 2000). Accordingly, the attributes, skills and knowledge acquired and enhanced by employees can increase levels of efficiency in the workplace and/or when switching companies by promoting the competitiveness of employees and the benefits for them, employers and the economy as a whole (Andrews and Russell, 2012).

In line with these ideas, our research aims to analyze the positive impact of perceived internal employability on satisfaction and commitment, and how these mediating variables negatively influence the intention to quit. 


\section{Theoretical Framework: Internal Employability and Intention to Quit Relationship}

According to Recommendation 195 of ILO's Human Resources Development of 2004, employability refers to the skills and transferable capabilities, thus enhancing the ability of people to take care advantage the education and training opportunities. The aim is to achieve goals such as finding and keeping a great job; progress within the company or change jobs and adapt to the evolution of technology and the different labor market conditions. Thus, employability is associated with a multidimensional and complex concept, in which learning and skills development is interpreted as continuity (Harvey, 2001). Employability cannot be considered a full guarantee of actual employment, but it can increase the chances for it (Nilsson and Ekberg, 2013).

In this sense, employability involves the ability to get a job, within or outside the organization (Fugate, Kinicki and Ashforth, 2004; Koen, Klehe and Van Vianen, 2013). This capability also empowers the professionals to perform a variety of positions and facilitates their mobility between jobs in the same or different organization (Morrison and Hall, 2002), and increases the chances of reemployment in unemployment situations (McArdle et al., 2007). Therefore, employability prepares the individual for the job, and to find a successful management of their different professional scenarios (McQuaid and Lindsay, 2005; Nilsson and Ellström, 2012).

We cannot forget the subjective appreciation that the individual makes about his opportunities of finding work, depending on the real situation of the labor market and certain personal characteristics (Ripoll et al., 1994). Following Gamboa et al. (2007), our research focuses on perceived employability, by relying on the perceptions that people have about their ability to obtain an employment.

On the other hand, it notes that internal employability determines the worker competitiveness level within the company; it establishes the professional profile to be developed by the employee with the aim of fit the organization training needs. This aspect, therefore, bets to enhance worker's ability to remain employed with their current employer (Groot and van den Brink, 2000). Moreover, Sanders and de Grip (2004), differ two types of internal employability: one that allows a professional continues working in the same job, and one that enables 'employable' individuals change jobs within the organization.

Regarding to intention to quit, a first overview of this construct is related to the idea that workers are considering leaving your current company, or even their profession (McNatt and Judge, 2008). This intention is more directly related to the will and the decision making that has got the individual to change his attitude and organizational behavior (Elangovan, 2001; Campbell and Campbell, 2003), as a result of a lack of adaptation in labour relations. In line with this idea, a professional tempted by the intention to quit their current situation in the company, it will be more probably that it is more motivated to investigate new employment prospects in order to find an alternative to its reality (Milliman, Czaplewski and Ferguson, 2003).

However, despite the trend of abandonment it is the most characteristic behavior related to this construct does not necessarily mean it will happen (Maertz and Campion, 2004). In this sense, this intention to leave corresponds to a subjective estimate and a probability, but not necessarily to a real fact (García Chas, Neira Fontela y Varela Neira, 2012). Therefore, while the actual behavior of abandonment is presented as the ultimate purpose of the worker, it is rather the intention which prevails as a strong substitute (Firth et al., 2004).

In this case, the intention to quit the firm is interpreted as an expression of disinterest of continuing working on it, as a feeling of wasting time and emotional exhaustion (Jaramillo, Mulki and Locander, 2006), but not always as a true resignation, especially if there are no alternatives in labor market. And, not all factors depend on the professional. This makes more often the worker may fall into remarkable job laziness (Mobley, 1982). In turn, this fact increases the absence of proactive and motivational behavior towards the organization and other colleagues (Judge and Klinger, 2007). 


\section{The Mediating Role of Job Satisfaction and Affective Organizational Commitment}

After study the importance of perceived internal employability, we consider the influence that this construct can have on intention to quit the company is mediated by job satisfaction and affective organizational commitment. So we defend that the perceptions that professionals have around their levels of job satisfaction and affective organizational commitment are critical for their retention in their current job and firm (Tymon Jr., Stumpf and Doh, 2010).

Locke (1976) considers job satisfaction as pleasant or positive emotional state resulting from the job evaluation or experiences in work. Therefore, job satisfaction is the emotional orientation that employees show to their organizational roles (Kalleberg, 1977). Authors like Beer (1964) and Peiró (1984) describe job satisfaction as an aspect beyond feelings and emotions, as the general attitude that employees have to work. This element is understood like subjective and is conditioned by the personality and the circumstances of each individual, and the environment changes (Diener et al., 1985). According to that, the greater or lesser development of job satisfaction will depend on the degree of compliance between the initial aspirations and truly made goals of the professionals (Pérez Rubio, 1997; Hamermesh, 2001).

Rockeach (1973) considers affective organizational commitment as the emotional and functional fixation that the employee has got with respect to their workplace. The commitment therefore not only is related to the degree of identification of the worker with the firm, but with the job and the contents of it. This variable also involves emotional and intellectual connection that the professional has with his work, organization, superiors and/or colleagues, thereby generating an additional discretionary effort into their work (Gibbons, 2006).

As is known, organizational commitment has three dimensions: affective, normative and continuity (Meyer and Allen, 1991). However, this research focuses on affective dimension as the closest to a positive feeling of general satisfaction with work. Affective commitment explains the link that worker must have with the organizational goals and values, as a result of emotional ties after satisfy the expectations and needs, especially psychological needs (Allen and Meyer, 1990). This affectivity leads to feelings such as care toward colleagues, feelings of belonging and loyalty (González and Guillen, 2007).

\section{Perceived Internal Employability and Job Satisfaction Relationship}

People become employable when they are in position to get a satisfactory job (Hillage and Pollard, 1998). This statement leads us to consider that for the development of individual employability it is important to have a positive predisposition and take the lead in this effort (van Dam, 2004; Gamboa et al., 2007). It is also a matter of personal and professional concern. Therefore, initiative linked to a good perception of the labor market opportunities, raises the internal and external job satisfaction indices (Gamboa et al., 2007), increasing the probability to get a job in accordance with the professional preferences.

People with high perceived employability indices are more actively involved in the different learning processes of the organization, enhancing their predisposition to change their present employment status. In this case, workers state as a primary objective the satisfaction of their own professional interest, moving forward in their desired career plan (Fugate et al., 2004). That is why inasmuch as the organization involved itself in this process facilitating continuously new job opportunities, job satisfaction of their employees will increase (Álvarez y Miles, 2006).

At this point, we must point out that the positive relationship between perceived internal employability and job satisfaction is strongly supported in the specialist literature. The promotion of internal employability can generate higher levels of satisfaction. One of the main reasons lies in the fact that the employee considers that he is of greater value for his firm and that increases the probability to keep his 
present job (De Witte, 2005). As far as the firm becomes involved in the internal employability process, facilitating new job opportunities as a motivational factor, employees' satisfaction will be higher (Álvarez y Miles, 2006). The implementation of career plans following agreed arrangements between the firm and the employee that involve social and labor internal promotion, favor the development of subjective well-being, which is a precursor of job satisfaction (D'Addio, Eriksson and Frijters, 2007). That is why we pose the following hypothesis:

H1(+): Employees with higher perceived internal employability, show higher levels of job satisfaction.

\section{Perceived Internal Employability and Affective Organizational Commitment Relationship}

Most managers consider that internal employability promotion, is a key factor, regarding their most valuable employees, because they understand that if good external employment options are available, the risk of brain drain may be high (Roehling et al., 2000). Without any doubt, this fact, reflects the importance for organizations of developing training and development activities (oriented to employment), that may be able to boost employees' affective commitment level (Fugate et al., 2004; van Dam, 2004), and a sense of responsibility and obligation (Hutchison, 1997) or, in other words, a higher level of normative commitment. Training and development programs cause employees to perceive the firm interest for their general labor well-being (Tansky and Cohen, 2001).

Firm's investment in specific and distinctive training and development programs for their present or potential key employees, is strongly related with internal promotion and virtually zero voluntary turnover (Benson, 2006). Nevertheless, the firm should not ignore voluntary turnover risk when employees discover a more engaging external job opportunity. Consistent with this idea, we consider that, a greater employee control about its own professional career, may favor to some extent intention to quit (Ito and Brotheridge, 2005). That is why, in order to avoid this risk, the organization must invest in activities that can foster employee loyalty, through incentives and/ or motivating contractual terms.

The employees more engaged with firm objectives and guidelines, will show a greater affective committed and a greater willingness to continue working for the same organization, because of their greater sense of ownership (Roehling et al., 2000). In this sense, employees strongly motivated to display their value inside the firm, will show greater commitment, as a mean to increase their probability to keep their current job (Connely and Gallagher, 2004; De Witte, 2005). That is why we pose the following hypothesis:

H2(+): Employees with greater perceived internal employability show a greater affective commitment.

\section{Job Satisfaction and Affective Organizational Commitment Relationship}

From an organizational point of view, job satisfaction is considered a more specific construct than commitment (Juaneda y González, 2007). Satisfaction is intrinsically linked to a specific job and to some labor aspects (Locke, 1976; Baker and Baker, 1999), while commitment is a more comprehensive construct, which reflects an overall response to the organization as a whole. These considerations make us think that to achieve commitment is necessary to build a strong interaction between psychological well-being and job satisfaction of employees (Wright and Bonnet, 2007). With this in mind, job satisfaction is seen as an antecedent of organizational commitment (Mathieu and Zajac, 1990; Mueller et al., 1994; Álvarez Pérez, Castro Casal y Vila Vázquez, 2014).

Pfeffer (1994) states that job involvement of employees is a key element to organizational success, since more involved employees are more motivated and, therefore, more satisfied with their job (Pérez y de la Garza, 2007). Such 
relevant attitudes and derived behaviors results in growing performance and organizational efficiency (Locke, 1976; Mathieu and Zajac, 1990; López-Araújo, Osca y Peiró, 2007). All this lead us to think that employees will decide to commit with organization if they fell happy and enthusiastic with it (Mañas et al., 2007). Finally, employees in positions perceived as enriched, challenging and less boring may be more predisposed to commit with their organization (Diego, Diego and Olivar, 2001). That is why we propose the following hypothesis:

H3(+): The more satisfied are employees, the greater their organizational affective commitment.

\section{Job Satisfaction and Intention to Quit Relationship}

There are several studies that support the idea that the greater or lesser degree of job satisfaction is one of the most significant determinants of the intention to quit, which is a precursor of voluntary turnover (Clegg, 1983; Williams and Hazer, 1986; Elangovan, 2001). Nevertheless, an unsatisfied employee that wants to quit job does not necessarily do so if the right conditions are not met, that is, if they cannot find an alternative employment. If the adverse situation persists and/ or it gets worse with time, he will feel increasingly unsatisfied and increasing need to quit job, but it will not do it if the necessary resources are lacking (Ladebo, 2005). In this case, instead of leaving their job, employees may display increasingly negative and dysfunctional affective behaviors, in their professional field (Becker, 1985).

Conversely, job enrichment, the development of effective participation practices and, in general, positive experiences at work will lead to better attitudes (Hackman and Oldham, 1975; Locke and Schweiger, 1979), a greater global wellbeing perception (Judge and Klinger, 2007), stronger engagement with organization, and lesser intention to quit job (Scott, Bishop and Chen, 2003). Consistent with this we propose the following hypothesis:
H4(-): Employees with higher levels of job satisfaction show lesser turnover intention.

\section{Affective Organizational Commitment and Intention to Quit Relationship}

There is significant evidence that commitment is negatively related with employee's voluntary turnover (Clegg, 1983; Williams and Hazer, 1986; Elangovan, 2001), and intention to quit job (Ladebo, 2005; Saks, 2006). High performance work practices systems may favor employee emotional attachment to organization (Paré and Tremblay, 2007). These strategies that put a strong emphasis in human resources, make employees feel more power and control over their own work, increasing levels of commitment and decreasing consequently intentions to leave the company (Paré and Tremblay, 2007) and can become an important source of competitive advantage for the organization.

People committed with the organization show lower levels of intention to quit, either because they want to stay (affective commitment), because a sense of obligation (normative commitment) or because they need to stay (continuance commitment) (Allen and Meyer, 1990). These arguments contribute to think that the decision of leaving the company of employees with high level of continuance commitment is related with an external locus of control (Higgins, 1997), and their decision is driven by job opportunities in the labor market. Nevertheless, our model focuses on the affective dimension of commitment, because we understand that this dimension is related with internal locus of control. We consider that as far as the organization invests in employees' development, the greater the affective commitment of these employees will be.

Bloemer and Odekerken-Schroder (2006), suggest that employees that tend to get involved with their employer are usually more loyal employees, both in terms of attitudes (high organizational commitment) and in terms of 
behavior (low intention to quit and voluntary turnover). Employees with high level of affective organizational commitment, are characterized by a strong internal motivation and a willingness to promote inside the company (Higgins, 1997; Meyer, Becker and van Dick, 2006), and show high levels of performance and low levels of absenteeism (Meyer et al., 2002; Sallan et al., 2010). According to the arguments above mentioned, we propose the following hypothesis:
H5(-): Employees with higher affective organizational commitment show lesser levels of intention to quit job.

The hypotheses proposed can be represented as indicated in figure 1. Our model focuses on the impact of the perceived internal employability on the ITQ by employees.

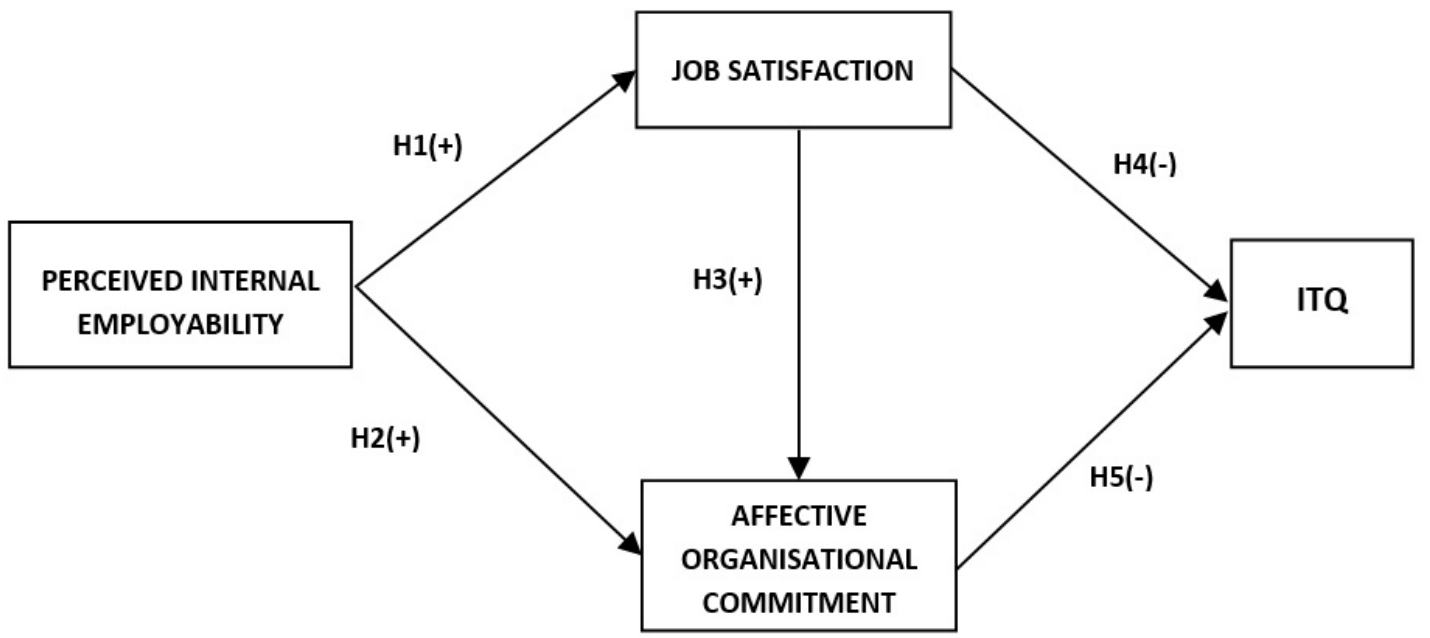

Figure 1. Impact of perceived internal employability on ITQ. Source: authors' own elaboration.

\section{Methodology}

\section{Data}

In order to empirically contrast the hypotheses proposed in the theoretical model, salaried workers employed under contract in private companies were chosen as the population for the analysis. The reason is that in these businesses the efforts made to enhance the employability of workers as a way to boost competitiveness are higher. Though no particular sector was singled out, the idea was for employees to have opportunities to access training schemes run by the companies to which they belonged so priority was given to companies with over 50 employees. Furthermore, to ensure geographical proximity, the study was limited to the province of Valencia (Spain). Finally, a sample of 218 employees was obtained, of which
166 worked in the services sector $(76.1 \%)$ and the remaining 52 in the industrial sector (23.9\%). Consequently, the sampling error obtained was $6.6 \%$ for a confidence level (significance) of $95 \%$.

The tool used for gathering the data was a questionnaire sent, through the platform Google Drive, via e-mail and as a hard copy, to a series of relevant firms in the geographical scope of our study once we had obtained permission to carry out the research from the human resources department.

\section{Measurement of the variables}

As said, the information was collected using a questionnaire which was divided into several sections matching the various constructs under study, besides an initial section devoted to general information. 
The set of items selected for the assessment of the constructs was based on the previous proposals of literature. However, before submitting the questionnaire to the companies, we understood fundamental to resort to a panel of six experts in the area of Human Resources, in order to improve the content validity of the scales (DeVellis, 1991; Alvarado-Herrera, Bigné and Aldás-Manzano, 2017) and reduce the ambiguity of the items chosen to measure each of the constructs (Hardesty and Bearden, 2004). These experts were with more than ten years of teaching and research experience and with a significant background and knowledge of the topics addressed in this paper. Specifically, they were requested about the need to include additional items, remove statements or change the wording of any of the items in order to remove any ambiguity. Once the final items to be considered had been decided, based on the suggestions and improvements from the panel of experts (table 1), they were assessed using a Likert scale of 1 to 5 points.
Table 1. Constructs and indicators

\begin{tabular}{lcl}
\hline \multicolumn{1}{c}{ Constructs } & \multicolumn{1}{c}{ Items } & \multicolumn{1}{c}{ Previous studies } \\
\hline $\begin{array}{l}\text { Internal } \\
\text { Employability }\end{array}$ & 5 items & $\begin{array}{l}\text { Delery and Doty (1996), Groot and van den Brink (2000), Fugate et al. (2004), Rego and } \\
\text { Souto (2004), Sanders and de Grip (2004), van Dam (2004), De Vos, De Hauw and Van } \\
\text { der Heijden (2011). }\end{array}$ \\
\hline Job Satisfaction & 6 items & $\begin{array}{l}\text { Cammann et al. (1979), Diener et al. (1985), Greenhaus, Parasuraman and Wormley } \\
\text { (1990), Nabi (2003), Chew and Chan (2008), Chow (2009). }\end{array}$ \\
\hline $\begin{array}{l}\text { Affective } \\
\begin{array}{l}\text { Organisational } \\
\text { Commitment }\end{array}\end{array}$ & 6 items & $\begin{array}{l}\text { Allen and Meyer (1990), Netemeyer et al. (1997), Yousef (1998), Mellor et al. (2001), } \\
\text { Zaleska and de Menezes (2007), Chew and Chan (2008). }\end{array}$ \\
\hline $\begin{array}{l}\text { Intention to Quit } \\
\text { Cammann et al. (1979), Moore (2000), Scott et al. (2003), Castiller (2006), Chew and }\end{array}$ \\
\hline
\end{tabular}

\section{Statistical analysis}

In order to empirically test our hypotheses, a covariance structure (structural equation) model for causal analysis was built using the IBM SPSS Amos 16.0 module. The scale's internal consistency or reliability was evaluated using Cronbach's alpha statistics. Equal to or greater than 0.7 were regarded as optimal values (Nunnally and Bernstein, 1994). However, certain authors, such as Hair et al. (1999), consider values of 0.6 and above to be acceptable for studies of an exploratory nature.

Additionally, an exploratory factor analysis of principal components was carried out with the idea of verifying the individual reliability of each of the indicators with its respective construct (convergent validity). The criterion used for accepting that the reflective indicators form part of the construct is a loading equal to or greater than 0.7. However, different researchers suggest that this empirical norm should not be quite so strict during the initial stages of scale development, and that loadings of 0.5 are also acceptable (Chin, 1998; Hair et al., 1999). For this study, we decided to use an acceptance criterion of 0.6 for factor loadings.

\section{Results}

After initial exploratory factor analysis followed by confirmatory factor analysis, it became clear that the job satisfaction and affective organizational commitment items appeared to be related but it was not possible to distinguish between the two constructs. These early findings meant that the research model had to be honed, finally producing the one depicted below in figure 2. 


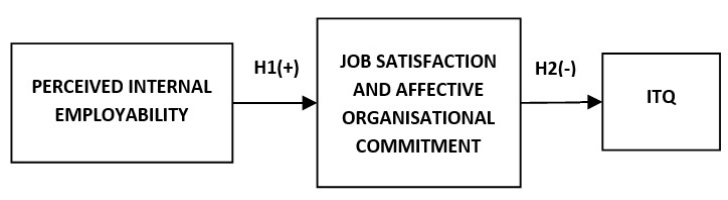

Figure 2. Final research model. Source: authors' own elaboration.

However, as can be seen in table 2, the Cronbach's values were very high (above 0.75 ) for each construct, so it can be stated that the constructs involved in our hypotheses did meet the measurement scale's reliability criteria.

Table 2. Cronbach's alpha value

\begin{tabular}{ll}
\hline \multicolumn{1}{c}{ Constructs } & \multicolumn{1}{c}{ Cronbach's alpha } \\
\hline $\begin{array}{l}\text { Internal } \\
\text { Employability }\end{array}$ & 0.752 \\
\hline Satisfaction and AOC & 0.937 \\
\hline ITQ & 0.911 \\
\hline
\end{tabular}

Source: authors' own elaboration.
As a consequence of the above methodological development and by way of summary (table 3 ), results showed that internal employability did positively and strongly impact on satisfaction and commitment in the same way that satisfaction and commitment negatively and strongly impacted on the intention to quit, thus entailing acceptance of the hypotheses proposed in the final research model.

Table 3. Hypothesis and model fit

\section{HYPOTHESIS STANDARDISED COEFFICIENTS T-STATISTIC VALUE HYPOTHESIS TEST}

\begin{tabular}{|c|c|c|c|c|}
\hline $\begin{array}{l}\text { Proposed relations } \\
\text { Internal employability -> }\end{array}$ & $\mathrm{H}_{1}$ & (ß31) $1.519^{\star \star \star}$ & 4.293 & Accepted \\
\hline $\begin{array}{l}\text { Satisfaction } \\
\text { and } A O C->\text { ITQ }\end{array}$ & $\mathrm{H}_{2}$ & $\left(\beta_{53}\right)-0.717^{\star \star \star}$ & -10.376 & Accepted \\
\hline \multicolumn{5}{|l|}{$\begin{array}{l}\text { Goodness of fit indexes } \\
\text { (model fit indexes) }\end{array}$} \\
\hline CMIN/DF & $1.686(<3)$ & & & \\
\hline $\mathrm{CFI}$ & $1.686(<3)$ & & & \\
\hline $\mathrm{CFI}$ & $\begin{array}{l}0.949 \\
(\sim>0.95)\end{array}$ & & & \\
\hline $\mathrm{GFI}$ & $\begin{array}{l}0.862 \\
(\sim 0.95)\end{array}$ & & & \\
\hline AGFI & $0.826(>0.80)$ & & & \\
\hline SRMR & $0.060(<0.08)$ & & & \\
\hline RMSEA & $0.056(<0.08)$ & & & \\
\hline
\end{tabular}

*Standardised coefficients significant at $90 \%$ confidence level.

$* \star$ Standardised coefficients significant at $95 \%$ confidence level.

$\star \star \star$ Standardised coefficients significant at $99 \%$ confidence level.

Source: authors' own elaboration. 


\section{Conclusions}

By way of conclusion, this research has enabled us to analyze and confirm the complexity of perceived internal employability among workers and how it reduces their intention to quit. Given the importance of perceptions in this field, we suggest that this relationship should be mediated by job satisfaction and affective organizational commitment, with satisfaction in turn being an antecedent of this affective commitment.

However, the first results of our research meant that these mediating variables had to be grouped together as it was not possible to distinguish between them. Here it should be noted that compared with rules and continuity, the affective dimension of organizational commitment is the one closest to a positive feeling of overall job satisfaction. This explains the employee's connection with the organization's objectives and values as a result of these emotional bonds forged by meeting their expectations and needs, especially psychological ones. This makes it significantly difficult to achieve high levels of discriminant validity on the measurement scales of both constructs as respondents were not able to clearly distinguish between the two concepts.

This leads us to conclude that internal employability does have a positive effect on job satisfaction and affective organizational commitment. If the company is positively involved in enhancing employability by continuously providing employment opportunities, its employees' wellbeing and engagement will rise. While there may be uncertainty at any given time about guaranteeing long-term employment in the same company, workers will recognize that committing to learning and employability is fair reward.

Thirdly, job satisfaction and affective organizational commitment negatively impacted on the intention to quit. Consistent with this, strong levels of wellbeing and engagement in employees strengthen the whole business over time by generating lower rates of voluntary staff turnover and absenteeism.

The academic implications of this paper are an improved grasp of the proposed model taking into account the importance and influence of perception on employees' behavior. Although the literature supports the relationship between each conjunction of variables, our research also enables us to empirically test the initial theory and study the changes that take place due to the adaptation of the model.

In terms of business implications, this paper shows how encouraging the development of internal employability by the company is likely to result in increased perception of professional recognition by employees because they can see that the organization counts on them and their worth. Such consideration may therefore increase work engagement rates as well as their satisfaction and confidence and strengthen the psychological contract between employer and employee.

Another of the business implications comes from the lower intention to quit of employees. If the company can reduce an employee's wish to leave the organization, this will help to diminish their level of maladjustment to their work and position, thereby increasing engagement with the company. This increase in employee commitment may prevent a rise in organizational costs by maintaining and/or growing levels of efficiency and effectiveness.

Regarding the main limitations, we highlight that although the chosen methodological approach provides a remarkable richness in the analysis, it is hard to extract generalizable conclusions, especially because of the adaptation of the model of research that has been needed. Consistent with this, a limitation is found in the unreliability of some of the indicators with their respective variables. Consequently, the constructs of job satisfaction and affective organizational commitment could not be studied separately.

In line with this idea, we consider that while the sample is correct, it has certain biases in size since a larger number of replies would have strengthened the results and bring greater consistency to the conclusions. Therefore, a greater number of responses on the questionnaire used and the correct reprocessing of the items appear as essential steps in order to get a better understanding. Finally, we must also take into account developments in the labor context in recent years. The crisis has strongly made 
precarious the work, reducing the opportunities for improvement. Since we work with perceptions, it is very likely that this has led employees to have lower expectations; i.e., to feel more satisfied with what they have when comparing with the situation of others and/or to resign for fear of a situation of joblessness and uncertainty. Thus, the results could be influenced by this reality.

As future research, it is essential to rethink the questionnaire as a measuring instrument, strengthening and specifying better the indicators of each of the constructs under study. The main purpose for this is to allow more powerful structural equation system utilization and thereby a greater understanding of the impact that each proposed relationship exerts on the organizational reality. It also raised the possibility of inclusion of new research variables, to expand and enrich our model and the proposed cause-effect relationships. As examples of these additional variables as determinants of perceived employability could be the age, sex, professional status, previous experience in a position and/or similar company, and professional recognition, among others. Finally, we do not have to forget the possibility of carrying out the study in other socioeconomic moment in which there may be more and better career opportunities. The results and conclusions obtained could be certainly changed, and the comparative study between the different stages could lead to highly relevant information.

\section{References}

Allen, N.J. and Meyer, J.P. (1990). The measurement and antecedents of affective, continuance, and normative commitment to the organization. Journal of Occupational Psychology, 63(1), 1-18.

Alvarado-Herrera, A., Bigné, E. and Aldás-Manzano, J. (2017). A Scale for Measuring Consumer Perceptions of Corporate Social Responsibility Following the Sustainable Development Paradigm. Journal of Business Ethics, 140(2), 243-262.

Álvarez, G.y Miles, D. (2006). El papel de la empleabilidad en la satisfacción laboral de los trabajadores temporales. Revista Galega de Economía, 15(2), $1-20$.

Álvarez Pérez, D., Castro Casal, C. y Vila Vázquez, G. (2014). Actitudes y engagement en el trabajo como antecedentes del comportamiento altruista. Revista Venezolana de Gerencia, 19(65), 23-42.

Andrews, G. and Russell, M. (2012). Employability skills development: Strategy, evaluation and impact. Higher Education, Skills and Work-Based Learning, 2(1), 33-44.

Baker, J.G. and Baker, D.F. (1999). Perceived ideological differences, job satisfaction and organizational commitment among psychiatrists in a community mental health center. Community Mental Health Journal, 35(1), 85-95.

Becker, G.S. (1985). A Theory of Competition among Pressure Groups for Political Influence. Quarterly Journal of Economics, 98(3), 371-400.

Beer, M. (1964). Organizational size and job satisfaction. Academy of Management Journal, 7(1), 34-44.

Benson, G.S. (2006). Employee development, commitment and intention to turnover: A test of "employability" policies in action. Human Resource Management Journal, 16(2), 173-192.

Bloemer, J. and Odekerken-Schroder, G. (2006). The role of employee relationship proneness in creating employee loyalty. International Journal of Banking Marketing, 24(4), 252-264.

Cammann, C. et al. (1979). The Michigan organizational assessment questionnaire. Ann Arbor, USA: University of Michigan. 
Campbell, D.J. and Campbell, K.M. (2003). Global versus facet predictors of intention to quit: Differences in a sample of male and female Singaporean managers and non-managers. The International Journal of Human Resource Management, 14(7), 1152-1177.

Castiller, R.R. (2006). The impact of gender and departmentclimateonjobsatisfactionandintentions to quit for faculty in science and engineering fields. The Journal of Technology Transfer, 31(3), 367-375.

Chew, J. and Chan, C. (2008). Human resource practices, organizational commitment and intention to stay. International Journal of Manpower, 29(6), 503-522.

Chin, W.W. (1998). Issues and opinion on structural equation modeling. Management Information Systems, 22(1), 7-17.

Chow, I. (2009). The Relationship Between Social Capital, Organizational Citizenship Behavior, and Performance Outcomes: An Empirical Study from China. SAM Advanced Management Journal, 74(3), 44-53.

Clegg, C.W. (1983). Psychology of employee lateness, absence, and turnover: A methodological critique and an empirical study. Journal of Applied Psychology, 68(1), 8-101.

Connely, C. and Gallagher, D. (2004). Emerging trends in contingent work research. Journal of Management, $30(6), 959-983$.

D’Addio, A.C., Eriksson, T. and Frijters, P. (2007). An Analysis of the Determinants of Job Satisfaction when Individuals' Baseline Satisfaction Levels May Differ. Applied Economics, 39(19), 2413-2423.

Delery, J.E. and Doty, D.H. (1996). Modes of Theorizing in Strategic Human Resource Management: Test of Universalistic, Contingency, and Configurational Performance Predictions. The Academy of Management Journal, 39(4), 802-835.

De Witte, H. (2005). Job Insecurity: Review of the International Literature on Definitions, Prevalence, Antecedents and Consequences. SA Journal of Industrial Psychology, 31(4), 1-6.

DeVellis, R. (1991). Scale development: Theory and applications. Thousand Oaks, USA: SAGE Publications.

De Vos, A., De Hauw, S. and Van der Heijden, B. (2011). Competency development and career success:
The mediating role of employability. Journal of Vocational Behavior, 79(2), 438-447.

Diego, R., Diego, A. and Olivar, S. (2001). Job satisfaction in banking workers. Psicothema, 13(4), 629-635.

Diener, E. et al. (1985). The Satisfaction with Life scale. Journal of Personality Assessment, 49(1), 71-75.

Elangovan, A.R. (2001). Causal ordering of stress, satisfaction and commitment, and intention to quit: A structural equations analysis. Leadership \& Organization Development Journal, 22(4), 159-165.

Fallows, S. and Steven, C. (2000). Building employability skills into higher education curriculum: A university-wide initiative. Education + Training, 42(2), 75-82.

Fernández-Mateo, I. (2002). La gestión de carreras. In Bonache, J. y Cabrera, A. (Ed.), Dirección estratégica de personas. Evidencias y perspectiva para el siglo XXI (pp. 231-262). Madrid, España: Prentice Hall.

Firth, L. et al. (2004). How can managers reduce employee intention to quit? Journal of Managerial Psychology, 19(2), 170-187.

Fugate, M., Kinicki, A. and Ashforth, B. (2004). Employability: A psycho-social construct, its dimensions, and applications. Journal of Vocational Behavior, 65(1), 14-38.

Gamboa, J. et al. (2007). La empleabilidad y la iniciativa personal como antecedentes de la satisfacción laboral. Valencia, España: Universitat de València.

García Chas, R., Neira Fontela, E. y Varela Neira, C. (2012). Percepciones de los sistemas de trabajo de alto rendimiento e intención de marcha. Un análisis multinivel. Investigaciones Europeas de Dirección y Economía de la Empresa, 18(3), 206-215.

Gibbons, J. (2006). Employee Engagement: A Review of Current Research and Its Implications. New York, USA: The Conference Board.

González, T.F. and Guillén, M. (2007). Organizational Commitment: A Proposal for a Wider Ethical Conceptualization of 'Normative Commitment.' Journal of Business Ethics, 78(3), 401-414.

Greenhaus, J.H., Parasuraman, S. and Wormley, W.M. (1990). Effects of Race on Organizational Experiences, Job Performance Evaluations, and Career Outcomes. Academy of Management Journal, 33(1), 64-86. 
Groot, W. and van den Brink, H.M. (2000). Education, training and employability. Applied Economics, 33(5), 573-581.

Hackman, J.R. and Oldham, G.R. (1975). Development of the job diagnostic survey. Journal of Applied Psychology, 60(2), 159-170.

Hair, J.F. et al. (1999). Análisis multivariante. Madrid, España: Prentice Hall.

Hamermesh, D.S. (2001). The changing distribution on job satisfaction. The Journal of Human Resources, 36(1), 1-30.

Hardesty, D.M. and Bearden, W.O. (2004). The use of expert judges in scale development: Implications for improving face validity of measures of unobservable constructs. Journal of Business Research, 57(2), 98-107.

Harvey, L. (2001). Defining and Measuring Employability. Quality in Higher Education, 7(2), 97-109.

Higgins, E.T. (1997). Beyond Pleasure and Pain. American Psychologist, 52(12), 1280-1300.

Hillage, J. and Pollard, E. (1998). Employability: Developing a Framework for Policy Analysis. London, England: Department for Education and Employment.

Hutchison, S. (1997). Perceived organizational support: Further evidence of construct validity. Educational and Psychological Measurement, 57(6), 1025-1034.

Ito, J.K. and Brotheridge, C.M. (2005). Does supporting employees' career adaptability lead to commitment, turnover, or both? Human Resource Management, 44(1), 5-19.

Jaramillo, F., Mulki, J.P. and Locander, W.B. (2006). The role of time wasted in sales force attitudes and intention to quit. International Journal of Bank Marketing, 24(1), 24-36.

Juaneda,E.yGonzález,L.(2007).Definición,antecedentes y consecuencias del compromiso organizativo. In Ayala Calvo, J.C. (Coord.), Conocimiento, innovación y emprendedores: camino al futuro (pp. 35903609). La Rioja, España: Universidad de La Rioja.
Judge, T.A. and Klinger, R. (2007). Job Satisfaction: Subjective Well-Being at Work. In Eid, M. and Larsen, R. (Ed.), The Science of Subjective Well-Being (pp. 393-413). New York, USA: The Guilford Press.

Kalleberg, A.L. (1977). Work Values and Job Rewards: A Theory of Job Satisfaction. American Sociological Review, 42(1), 124-143.

Koen, J., Klehe, U.C. and van Vianen, A.E.M. (2013). Employability among the long-term unemployed: A futile quest or worth the effort? Journal of Vocational Behavior, 82(1), 37-48.

Ladebo, 0.J. (2005). Effects of Work-related Attitudes on the Intention to Leave the Profession: An Examination of School Teachers in Nigeria. Educational Management Administration \& Leadership, 33(3), 355-369.

Locke, E.A. (1976). The nature and causes of job satisfaction. In Dunnette, M.D. (Ed.), Handbook of industrial and organizational psychology (pp. 12971349). Chicago, USA: Rand McNally.

Locke, E.A. and Schweiger, D.M. (1979). Participation in decision-making: One more look. Research in Organizational Behavior, 1(10), 265-339.

López-Araújo, B., Osca, A. y Peiró, J.M. (2007). El papel modulador de la implicación con el trabajo en la relación entre el estrés y la satisfacción laboral. Psicothema, 19(1), 81-87.

Maertz, C.P. Jr. and Campion, M.A. (2004). Profiles in Quitting: Integrating Process and Content Turnover Theory. Academy of Management Journal, 47(4), 566-582.

Mañas, M.A. et al. (2007). La satisfacción y el bienestar psicológico como antecedentes del compromiso organizacional. Psicothema, 19(3), 395-400.

Mathieu, J.E. and Zajac, D.M. (1990). A review and meta-analysis of the antecedents, correlates and consequences of organizational commitment. Psychological Bulletin, 108(2), 171-194.

McArdle, S. et al. (2007). Employability during unemployment: Adaptability, career identity and human and social capital. Journal of Vocational Behavior, 71(2), 247-264.

McNatt, B. and Judge, T.A. (2008). Self-efficacy intervention, job attitudes, and turnover: A field experiment with employees in role transition. Human Relations, 61(6), 783-810. 
McQuaid, R.W. and Lindsay, C. (2005). The concept of employability. Urban Studies, 42(2), 197-219.

Mellor, S. et al. (2001). Employees' nonwork obligations and organizational commitments: A new way to look at the relationships. Human Resource Management, 40(2), 171-184.

Meyer, J.P. and Allen, N.J. (1991). A Three-Component Conceptualization of Organizational Commitment. Human Resource Management Review, 1(1), 61-89.

Meyer, J.P., Becker, T.E. and van Dick, R. (2006). Social identities and commitments at work: Toward an integrative model. Journal of Organizational Behavior, 27(5), 665-683.

Meyer, J.P. et al. (2002). Affective, continuance and normative commitment to the organization: A meta-analysis of antecedents, correlates, and consequences. Journal of Vocational Behavior, 61(1), 20-52.

Milliman, J., Czaplewski, A.J. and Ferguson, J. (2003). Workplace spirituality and employee work attitudes: An exploratory empirical assessment. Journal of Organizational Change Management, 16(4), 426-447.

Mobley, W.H. (1982). Some Unanswered Questions in Turnover and Withdrawal Research. Academy of Management Review, 7(1), 111-116.

Moore, E. (2000). One Road to Turnover: An Examination of Work Exhaustion in Technology Professionals. MIS Quarterly, 24(1), 141-168.

Morrison, R.F. and Hall, D.T. (2002). Career adaptability. In Hall, D.T. (Ed.), Careers in and out of organizations (pp. 205-232). San Francisco, USA: Jossey-Bass.

Moynihan, D.P. and Pandey, S.K. (2008). The Ties that Bind: Social Networks, Person-Organization Value Fit, and Turnover Intention. Journal of Public Administration Research and Theory, 18(2), 205227.

Mueller, C.W. et al. (1994). Employee attachment and noncoercive conditions of work: The case of dental hygienists. Work and Occupations, 21(2), 179-212.

Nabi, G. (2003). Situational characteristics and subjective career success. The mediating role of career-enhancing strategies. International Journal of Manpower, 24(6), 653-671.
Netemeyer, R.G. et al. (1997). An investigation into the antecedents of organizational citizenship behaviors in a personal selling context. Journal of Marketing, 61(3), 85-98.

Nilsson, S. and Ekberg, K. (2013). Employability and work ability: Returning to the labour market after long-term absence. WORK: A Journal of Prevention, Assessment and Rehabilitation, 44(4), 449-457.

Nilsson, S. and Ellström, P.E. (2012). Employability and talent management: Challenges for HRD practices. European Journal of Training and Development, 36(1), 26-45.

Nunnally, J.C. and Bernstein, I.H. (1994). Psychometric Theory. New York, USA: McGraw-Hill.

Paré, G. and Tremblay, M. (2007). The Influence of High-Involvement Human Resources Practices, Procedural Justice, Organizational Commitment, and Citizenship Behaviors on Information Technology Professionals' Turnover Intentions. Group \& Organization Management, 32(3), 326357.

Peiró, J.M. (1984). Psicología de la organización. Madrid, España: UNED.

Pérez Rubio, J.A. (1997). Motivación y satisfacción laboral: retrospectiva sobre sus formas de análisis. Reis. Revista Española de Investigaciones Sociológicas, 80, 133-167.

Pérez, R.C. y de la Garza, M.T. (2007). Comportamiento organizacional y satisfacción laboral. Revista Panorama Administrativo, 2(3), 99-108.

Pfeffer, J. (1994). Competitive advantage through people: Unleashing the power of the work force. Boston, USA: Harvard Business School Press.

Pfeffer, J. (2007). Human resources from an organizational behaviour perspective: Some paradoxes explained. Journal of Economic Perspectives, 21(4), 115-134.

Rego, A. y Souto, S. (2004). La relación entre los climas organizacionales autentizóticos y las variables intención de salida de la organización, el compromiso organizacional y el estrés. Revista Latinoamericana de Administración, 32, 77-101. 
Riddell, W.C. and Sweetman, A. (2000). Human Capital Formation in a Period of Rapid Change. In Craig Riddell, W. and St-Hilaire, F. (Ed.), Adapting public policy to a labour market in transition (pp. 85-141). Montreal, Canada: Institute for Research on Public Policy.

Ripoll, P. et al. (1994). Perspectivas de empleo. Los jóvenes ante el ambiente laboral y las estrategias de adaptación. Valencia, España: Nau Llibres.

Roehling, M. et al. (2000). The nature of the new employment relationship: A content analysis of the practitioner and academic literatures. Human Resource Management, 39(4), 305-320.

Rockeach, M. (1973). The nature of human values and value systems. The Nature of Human Values (pp. 3-25). New York, USA: Free Press.

Saks, A.M. (2006). Antecedents and consequences of employee engagement. Journal of Managerial Psychology, 21(7), 600-619.

Sallan, J.M. et al. (2010). Estudio de la relación entre el compromiso organizativo y la intención de abandonar la organización: modelo de dos componentes de compromiso de continuidad. Cuadernos de Gestión, 10(2), 15-28.

Sanders, J. and de Grip, A. (2004). Training, task flexibility and the employability of low-skilled workers. International Journal of Manpower, 25(1), 73-89.

Scott, K.D., Bishop, J.W. and Chen, X. (2003). An examination of the relationship of employee involvement with job satisfaction, employee cooperation, and intention to quit in US invested enterprise in China. International Journal of Organizational Analysis, 11(1), 3-19.

Tansky, J.W. and Cohen, D.J. (2001). The Relationship Between Organizational Support, Employee Development, and Organizational Commitment: An Empirical Study. Human Resource Development Quarterly, 12(3), 285-300.

Tymon Jr., W.G., Stumpf, S.A. and Doh, J.P. (2010). Exploring talent management in India: The neglected role of intrinsic rewards. Journal of World Business, 45(2), 109-121.

Van Dam, K. (2004). Antecedents and consequences of employability orientation. European Journal of Work and Organizational Psychology, 13(1), 29-51.
Williams, L.J. and Hazer, J.T. (1986). Antecedents and consequences of satisfaction and commitment in turnover models: A reanalysis using latent variable structural equation methods. Journal of Applied Psychology, 71(2), 219-231.

Wright, T.A. and Bonnet, D.G. (2007). Job Satisfaction: and Psychological Well-Being as Nonadditive Predictors of Workplace Turnover. Journal of Management, 33(2), 141-160.

Yousef, D.A. (1998). Satisfaction with job security as a predictor of organizational commitment and job performance in a multicultural environment. International Journal of Manpower, 19(3), 184-194.

Zaleska, K.J. and de Menezes, L.M. (2007). Human Resources development practices and their association with employee attitudes: Between traditional and new careers. Human Relations, 60(7), 987-1018. 